\title{
Heartwood and sapwood in eucalyptus trees: non-conventional approach to wood quality
}

\author{
SABRINA G. CHERELLI ${ }^{1}$, MARIA MÁRCIA P. SARTORI ${ }^{2}$, ANDRÉ \\ G. PRÓSPERO ${ }^{3}$ and ADRIANO W. BALLARIN ${ }^{1}$ \\ ${ }^{1}$ Universidade Estadual Paulista/UNESP, Departamento de Engenharia Rural, \\ Fazenda Lageado, Rua José Barbosa de Barros, 1780, 18603-970 Botucatu, SP, Brazil \\ ${ }^{2}$ Universidade Estadual Paulista/UNESP, Departamento de Produção e Melhoramento Vegetal, \\ Fazenda Lageado, Rua José Barbosa de Barros, 1780, 18603-970 Botucatu, SP, Brazil \\ ${ }^{3}$ Universidade Estadual Paulista/UNESP, Departamento de Física e Biofísica, Rua Prof. \\ Dr. Antonio Celso Wagner Zanin, s/n, 18618-689 Botucatu, SP, Brazil
}

Manuscript received on April 12, 2016; accepted for publication on July 25, 2016

\begin{abstract}
This study evaluated the quality of heartwood and sapwood from mature trees of three species of Eucalyptus, by means of the qualification of their proportion, determination of basic and apparent density using nondestructive attenuation of gamma radiation technique and calculation of the density uniformity index. Six trees of each species (Eucalyptus grandis - 18 years old, Eucalyptus tereticornis - 35 years old and Corymbia citriodora -28 years old) were used in the experimental program. The heartwood and sapwood were delimited by macroscopic analysis and the calculation of areas and percentage of heartwood and sapwood were performed using digital image. The uniformity index was calculated following methodology which numerically quantifies the dispersion of punctual density values of the wood around the mean density along the radius. The percentage of the heartwood was higher than the sapwood in all species studied. The density results showed no statistical difference between heartwood and sapwood. Differently from the density results, in all species studied there was statistical differences between uniformity indexes for heartwood and sapwood regions, making justifiable the inclusion of the density uniformity index as a quality parameter for Eucalyptus wood.
\end{abstract}

Key words: gamma radiation, image analysis, Eucalyptus, density uniformity index.

\section{INTRODUCTION}

Wood is a heterogeneous material formed by a set of cells with specific properties to perform the main functions of water conduction, storage of biochemicals and mechanical support of the plant body. The search for an interpretation increasingly detailed and in-depth of this complex and

Correspondence to: Sabrina Galetti Cherelli

E-mail: sabrina_galetti@hotmail.com multifunctional system is a permanent scientific challenge. Today, with the availability of more potential equipments and techniques, themes once studied partially or with limitations, gain new perspectives of analysis.

Wood of most trees can be divided into two distinct regions in terms of their physiological activity: sapwood and heartwood. These regions are identified in many species, although their 
occurrence, properties and color can vary (Hillis 1987).

Quantification of these regions is possible, in some species, by direct visual analysis of the wood due to pronounced differences in color between sapwood and heartwood conferred by the accumulation of extractives. The central portion (heartwood) is darker than the peripheral one (near the bark) which is clearer (sapwood). However, in certain species, despite the existence of heartwood, there are little or almost no visually detected differences between heartwood and sapwood colors. In such cases, identification requires the analysis of differences in the chemical level as a difference in $\mathrm{pH}$ between the sapwood and heartwood (Hillis 1987, McKimm 1985, Campbell et al. 1990, Winandy and Morrell 1993, Clarke et al. 1997) or the observation of anatomical features - tyloses may also be used to distinguish heartwood from sapwood but only in species where such features are closely associated with heartwood formation (Bamber and Fukazawa 1985). These authors state that this is the most appropriate method for the Eucalyptus genus. The application of X-ray densitometry can also be extremely useful to identify the sapwood - heartwood boundaries, based on different wood properties and levels of X-ray attenuation (Tomazello Filho et al. 2008).

There are marked differences between the heartwood and sapwood, which may be interesting or not, depending on the use of wood. Heartwood contains more extractives than the sapwood (Miranda et al. 2006), higher lignin content (Lachenbruch et al. 2011), and generally, less cellulose and holocellulose (Chen 1991, Shupe et al. 1997). Concerning hemicelluloses, only small differences have been observed between heartwood and sapwood (Holmbom et al. 2000); the heartwood has a lower moisture content due to reduced physiological activity; the heartwood is less permeable and has more compact tissue than the sapwood (Burger and Richter 1991); due to the extractives content of heartwood (which usually increases steadily from pith to periphery of the heartwood) it influences wood density (Kai 1991, Singleton et al. 2003, Grabner et al. 2005, Pillai et al. 2013); the strength is closely correlated with the density, thus strength differences may exist between heartwood and sapwood. However, heartwood does not differ structurally from sapwood; any significant strength differences result from radial changes in wood density and cell wall ultra-structure, not whether the sample is heartwood or sapwood (Panshin and De Zeeuw 1980); the heartwood usually has a higher natural durability due to the absence of nutritious materials (carbohydrates, mainly in the form of starch), and especially to the presence of extractives (Bamber 1981, Oliveira et al. 1986, Wiedenhoeft 2012).

Such anatomical and functional differences promote very different behavior of heartwood and sapwood from both physical and chemical point of view. Wilkes (1991) reports that while the sapwood is preferable for the production of pulp for paper - low content of extractives - the heartwood is used for construction with higher requirements of finishing, furniture industry, for example, due to its characteristics of greater natural resistance.

The variation in the proportion and characteristics of heartwood have been the subject of several reviews and vary with a large number of factors, including species, age, position in the tree, genetics, growth rate, leaf area, environmental parameters, as soil, climate, site quality, tree vitality, and forestry management (Smith et al. 1966, Hillis 1971, 1972, 1984, 1987, Bamber 1976, Panshin and De Zeeuw 1980, Wilkins 1989a, b, Wilkes 1991, Hazenberg and Yang 1991, Yang and Hazenberg 1991, Kort 1992).

The largest density variation within the stem is usually associated with the radial direction, and its measurements suggest possible end uses of wood (Bodig and Jayne 1993). The mean density of the wood can be measured with reasonable accuracy 
by conventional methods, but its variation within a sample is more accurately measured by radiological methods such as X-ray and attenuation of gamma radiation.

Several authors, in pioneer studies (1970s and 1980s), observed that the basic density values increased from pith to bark for eucalyptus species. For Eucalyptus grandis adult trees (23 years old), Oliveira et al. (2012) observed this same tendency. In more recent studies, with younger trees $(<20$ years old), Trevisan et al. (2008), Arantes (2009), Pinheiro (2013) and Pereira et al. (2013), reported lower density values in the heartwood region increasing gradually toward the bark reaching maximum values very close to the bark, in sapwood region.

Due to the importance of the proportion of heartwood and sapwood, its density variations as well as uniformity in the use of wood in certain applications and the possibility of using greater potential techniques to deeply differentiate these regions, this study aimed to quantify and physically qualify the wood of heartwood and sapwood of the three species of eucalyptus and suggest a new tool that is not mean density for evaluating the quality of the wood.

\section{MATERIALS AND METHODS}

\section{SAMPLING PROCEDURES}

Six trees of the following species were selected and harvested from plantation originally established with $2 \mathrm{~m} \times 3 \mathrm{~m}$ planting spacing.

- Eucalyptus grandis Hill ex. Maiden (18 years old) provided by the College of Agricultural Sciences of Botucatu are from Lageado Experimental Farm, Botucatu, São Paulo State, Brazil (22051'55" S; 48²6'22" $\mathrm{W})$;

- Corymbia citriodora (28 years old) provided by PREMA Tecnologia e Cormércio Ltda are from Ecological Station Mogi Guaçu, Mogi
Guaçu, São Paulo State, Brazil (22 $16^{\prime} 50^{\prime \prime}$ $\mathrm{S} ; 47^{\circ} 3$ '19" W);

- Eucalyptus tereticornis (35 years old) provided by PREMA Tecnologia e Comécio Ltda are from Casa Grande Farm, Corumbataí, São Paulo State, Brazil (22 $\left.2^{\circ} 13^{\prime} 6^{\prime \prime} \mathrm{S} ; 4^{\circ} 31^{\prime} 21^{\prime \prime} \mathrm{W}\right)$.

Two disks at breast height (DBH) were obtained from each tree: one for characterization and quantification of heartwood and sapwood and another for the determination of basic and apparent density with the use of attenuation gamma radiation technique. All the disks were peeled, planed in a lathe, and sanded with orbital sander to acquire uniform thickness $(20 \mathrm{~mm}$ for the disk to quantification of heartwood and sapwood and $30 \mathrm{~mm}$ for the disk to attenuation gamma radiation technique); the disks were stored to equilibrium in a climate-controlled room under $65 \%$ relative humidity and $21{ }^{\circ} \mathrm{C}$ (approximately 12\% EMC equilibrium moisture content).

\section{DELIMITATION OF THE HEARTWOOD AND SAPWOOD}

The cross section of the disks was polished (sequence of sand papers) and analyzed in a stereomicroscope of $10 \times$ increase. The heartwood was characterized by the presence of tyloses in the vessels (Figure 1).

The boundary between heartwood and sapwood was marked with a fine-tipped pen and high quality photographs of the disks were obtained using a digital camera (Fujifilm FinePix S2950 14 MP with Fujinon 18x Wide Angle Optical Zoom Lens and 3-Inch LCD) and a black background with the presence of a scale of $1 \mathrm{~cm}^{2}$ (graph paper). Photos were analyzed by digital image processing (computational algorithm in MatLab ${ }^{\circledR}$ platform version 7.12.0 -R2011a) for the determination of total areas of heartwood and sapwood (Figure 2). 


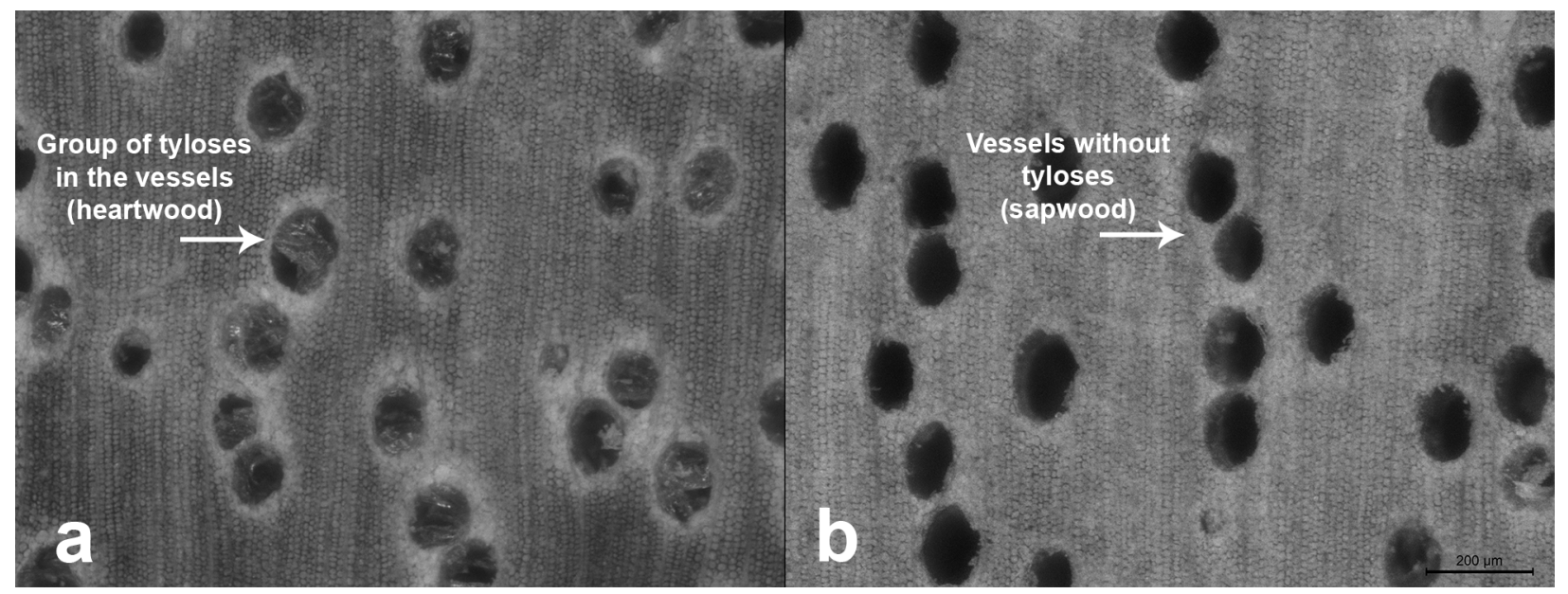

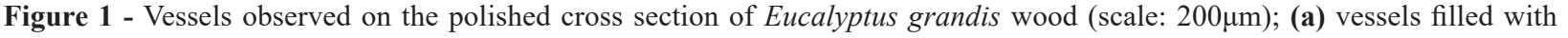
tyloses, disc area characterized as heartwood; (b) vessels without tyloses, disk area characterized as sapwood.
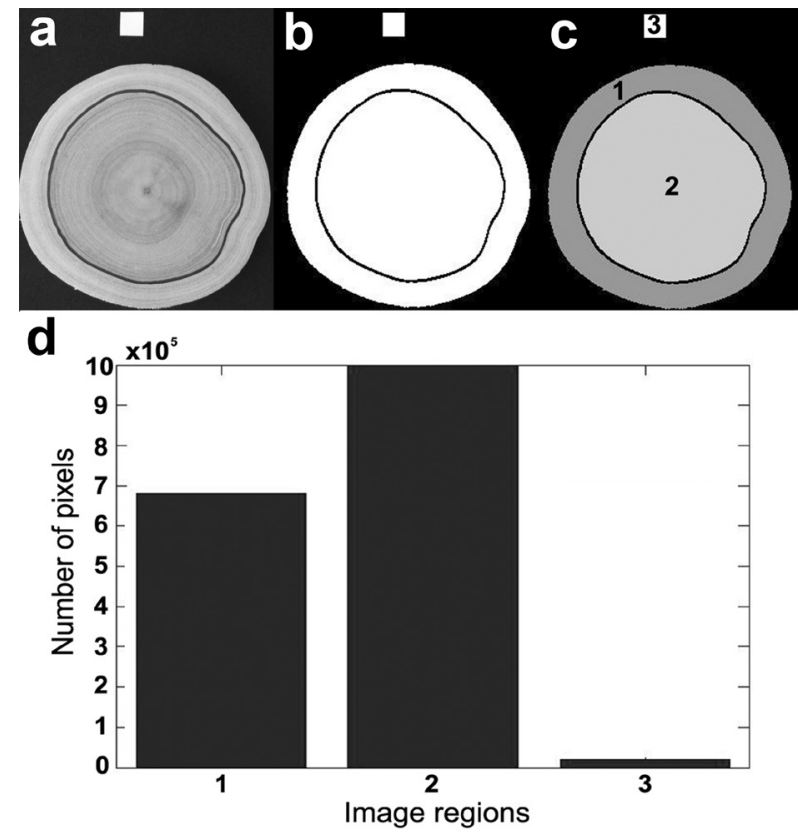

Figure 2 - Example of the stages of digital analysis of the Corymbia citriodora disk: (a) acquisition of high quality image; (b) binarization and highlight of the border of the image; (c) separation and recognition of interconnected regions; (d) Final histogram for the calculation of areas and percentages of regions.

\section{APPARENT DENSITY (12\% MOISTURE CONTENT)}

The apparent density of the wood (mass and volume at $12 \% \mathrm{MC}$ ) of the disks was determined by the attenuation gamma radiation technique (Figure 3). For this technique the average radius of the disk was used for the evaluation of density variation in the radial direction of the wood. Although the technique has been applied only to the average radius of the disc, these were kept entirely to facilitate the positioning of the material in the equipment.

This equipment is basically composed of: a radial source with radioisotope ${ }^{241} \mathrm{Am}$ (Rezende et al. 1998, Palermo et al. 2004), a solid scintillation detector system with a crystal of sodium iodide with traces of thallium, a signal conversion board A/D (Analog / Digital) for supplying the values of I and $\mathrm{I}_{0}$, and an electromechanical apparatus for the automatic movement of the sample - wood disks.

Density was determined by differential absorption of radiation (Parrish 1961, Ferraz and Mansel 1979), i.e., the higher the density, the greater the absorption and the lower the amount of radiation that passes through the absorber material. Equation 1 calculates the punctual density (adaptation to the Beer-Lambert law), with corrections provided by equation 2 and 3 due to the dead time of the electronic system.

$$
\begin{aligned}
& \rho_{U}=\frac{\ln \left(I_{0 C}-B G\right)-\ln \left(I_{C}-B G\right)}{\mu_{m} \cdot \chi_{m}} \\
& I_{0 C}=\frac{I_{0}}{1-\tau I_{0}}
\end{aligned}
$$




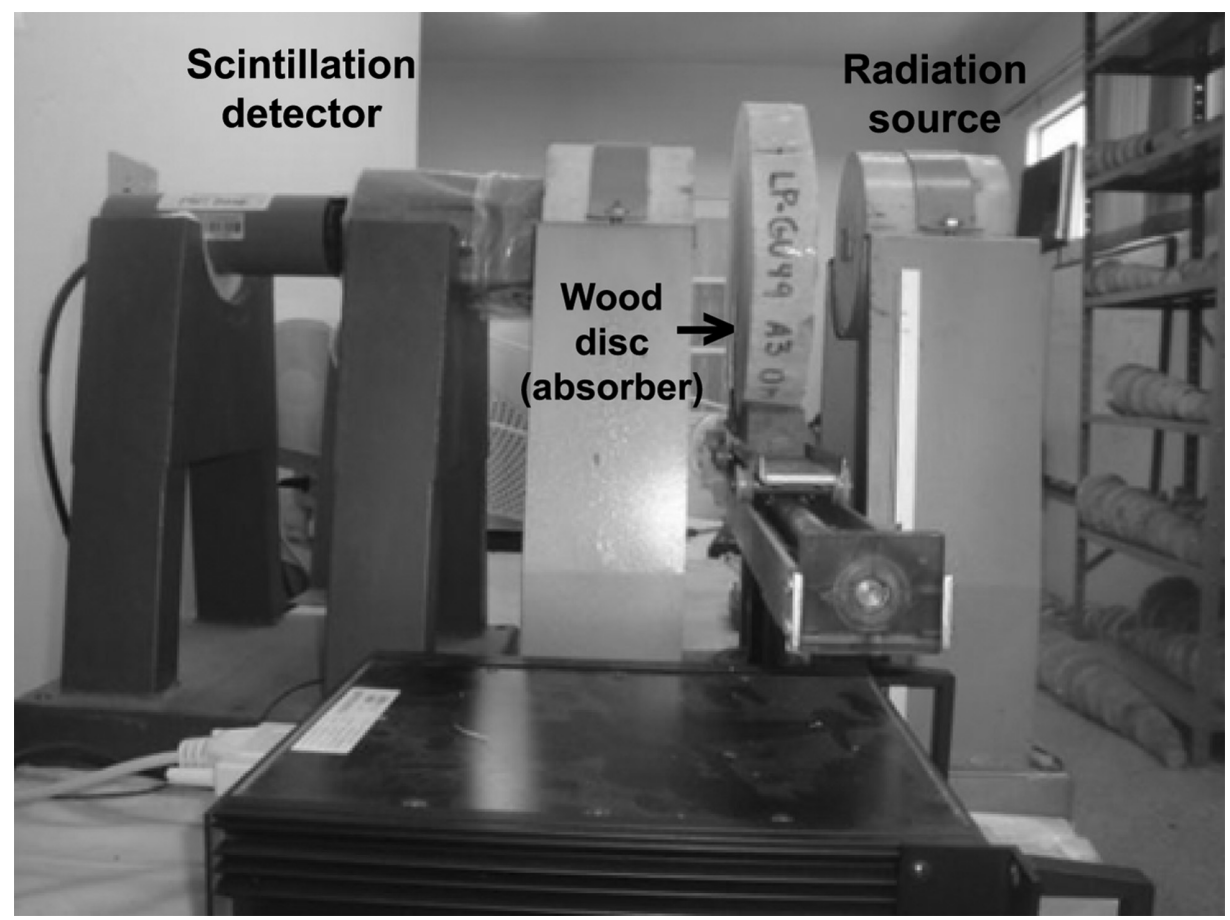

Figure 3 - Attenuation gamma radiation technique (Side detail of the sample movement between the source of radiation emission and the detection system).

$$
I_{c}=\frac{I}{1-\tau I}
$$

where $\rho_{\mathrm{U}}$ is the wood density at a given moisture content (U); $\mu_{\mathrm{m}}$ is the mass attenuation coefficient of wood, in $\mathrm{cm}^{2} \cdot \mathrm{g}^{-1} ; \chi_{\mathrm{m}}$ is the thickness of the wood specimen in $\mathrm{cm}$; $\mathrm{BG}$ is the background radiation counts per minute; $I_{0}$ is a counting rate (counts per minute) obtained experimentally without absorbing material; $I$ is a counting rate (counts per minute) obtained experimentally after passage through the absorber material (wood); $I_{0 c}$ is a $I_{0}$ value corrected due to the dead time of the electronic system by Equation 1 ; Ic is the $I$ value corrected due to the dead time of the electronic system by Equation 2 and $\tau$ is the is a dead time electronics system $(1.0 \times$ $10^{-7}$ minutes).

The disks at EMC were positioned in the equipment and slowly displaced to cross the radiation source at a speed adjusted to take 2 points of attenuation per millimeter across the average radius and construction of the apparent density profile.
Density profiles across the radius of the disks were used for two distinct evaluation methods: weighted mean density of the wood (entire disk) and its fractions (heartwood and sapwood) and calculation of the density uniformity index for wood and for the two fractions (heartwood and sapwood) separately, based on their punctual values in these regions.

The weighted mean density of each region of interest - heartwood and sapwood - was calculated separately using the delimitation of these regions and the assumption that the disk is formed by several thin and concentric rings with constant thickness: at the central region of the disk is the heartwood and, in the peripheral ring is the sapwood. The juxtaposition of rings, one within another, reconstitutes the disc. Knowing the density at one point of each ring, it is assumed that this density is the mean density of the ring. The weighted mean density of the disk is obtained by weighting the point densities in the rings, wherein the weighting factor is the volume of the ring, i.e., the density of 
the ring with highest volume is more representative in the weighted average value of density.

The weighted mean density was calculated at the EMC of the sample (U) - $r_{u}$ - and then transformed into weighted basic density $\left(\rho_{\mathrm{b}}\right)$ and weighted density at $12 \% \mathrm{MC}\left(\rho_{12}\right)$ by the equations 4, 5 and 6 proposed by Rezende (1997) and Rezende et al. (1998) and applied to Pinus and Eucalyptus.

$\rho_{0}=\frac{\rho_{U}}{(1+0,01 U \%)\left[(1-0,0013 U \%)-0,0050 U \% \rho_{0}\right]}$

$\rho_{b}=\frac{0,98 \rho_{0}}{1+0,24 \rho_{0}}$

$\rho_{12}=1,104 \rho_{0}-0,067 \rho_{0}{ }^{2}$

where $\rho_{\mathrm{U}}$ is the weighted apparent density at $\mathrm{U} \%$ humidity, $\rho_{0}$ is the weighted apparent density at $0 \%$ humidity, $\rho_{\mathrm{b}}$ is the weighted basic density and $\rho_{12}$ is the weighted apparent density at $12 \%$ moisture content.

The uniformity index (Echols 1973) numerically quantifies the dispersion around the average density of punctual density values of the wood along the region under evaluation of the sample. Using the histogram of punctual densities, taking the class that contain the average - reference class - and its contiguous (upper and lower) with weight 1 , to the other classes are assigned incremental weights $(2,3,4$, etc), which increase as they move away from the referential. The uniformity index is obtained by the sum of multiplications of the frequencies of each class by their respective weights. By this methodology, one ideally uniform wood would have only three frequency classes (referential and its two contiguous) and a uniformity index of 100 . The higher the index, the lower would be the uniformity of the wood. In this study, for all species, frequency classes with amplitude of $50 \mathrm{~kg} . \mathrm{m}^{-3}$ were used.

\section{RESULTS}

\section{AREAS AND PROPORTIONS IN HEARTWOOD AND SAPWOOD REGIONS}

It can be observed (Table I) that heartwood area is larger than the sapwood one for all species and the Eucalyptus grandis showed the largest total area among species.

The mean values of the heartwood area $\left(\mathrm{cm}^{2}\right)$ ranged from 345.5 to 589.8 , percentage of heartwood area ranged from 60.8 to $76.0 \%$ and the heartwood/sapwood relation ranged from 1.6 to 3.2 .

\section{BASIC AND APPARENT WEIGHTED MEAN DENSITIES IN HEARTWOOD AND SAPWOOD}

Figure 4 shows the densitometric profile of one disc (Eucalyptus grandis - sample no. 6) where it

TABLE I

Mean values (followed by standard deviation) of the area $\left(\mathrm{cm}^{2}\right)$ and percentage area of the heartwood and sapwood regions and relation heartwood/sapwood of the disks for the species.

\begin{tabular}{|c|c|c|c|c|c|c|}
\hline \multirow[b]{2}{*}{ Species } & \multicolumn{3}{|c|}{ Area $\left(\mathrm{cm}^{2}\right)$} & \multicolumn{2}{|c|}{ Area (\%) } & \multirow[b]{2}{*}{$\begin{array}{c}\text { Heartwood/ } \\
\text { Sapwood }\end{array}$} \\
\hline & Heartwood & Sapwood & Disk* & Heartwood & Sapwood & \\
\hline C. citriodora & $345.5(72.2)$ & $219.9(39.3)$ & $565.4(88.7)$ & $\begin{array}{c}60.8 \\
(5.9)^{\mathrm{bA}}\end{array}$ & $\begin{array}{c}39.2 \\
(5.9)^{\mathrm{aB}}\end{array}$ & $\begin{array}{c}1.6 \\
(0.4)^{b}\end{array}$ \\
\hline E. tereticornis & $444.4(48.0)$ & $139.4(13.7)$ & $583.8(42.8)$ & $\begin{array}{c}76.0 \\
(3.1)^{\mathrm{aA}}\end{array}$ & $\begin{array}{c}24.0 \\
(3.1)^{\mathrm{bB}}\end{array}$ & $\begin{array}{c}3.2 \\
(0.6)^{\mathrm{a}}\end{array}$ \\
\hline E. grandis & $589.8(142.5)$ & $284.6(58.6)$ & $874.5(172.2)$ & $\begin{array}{c}66.9 \\
(6.4)^{\mathrm{bA}}\end{array}$ & $\begin{array}{c}33.1 \\
(6.4)^{\mathrm{bB}}\end{array}$ & $\begin{array}{c}2.1 \\
(0.6)^{b}\end{array}$ \\
\hline
\end{tabular}

In the same column, average followed by at least one lowercase same letter do not differ by Tukey test $(\mathrm{p}<0.05)$. In the same line values followed by at least one uppercase letter do not differ by Student's test $(\mathrm{p}<0.05)$.

*Disk means the entire disk (heartwood+sapwood). 


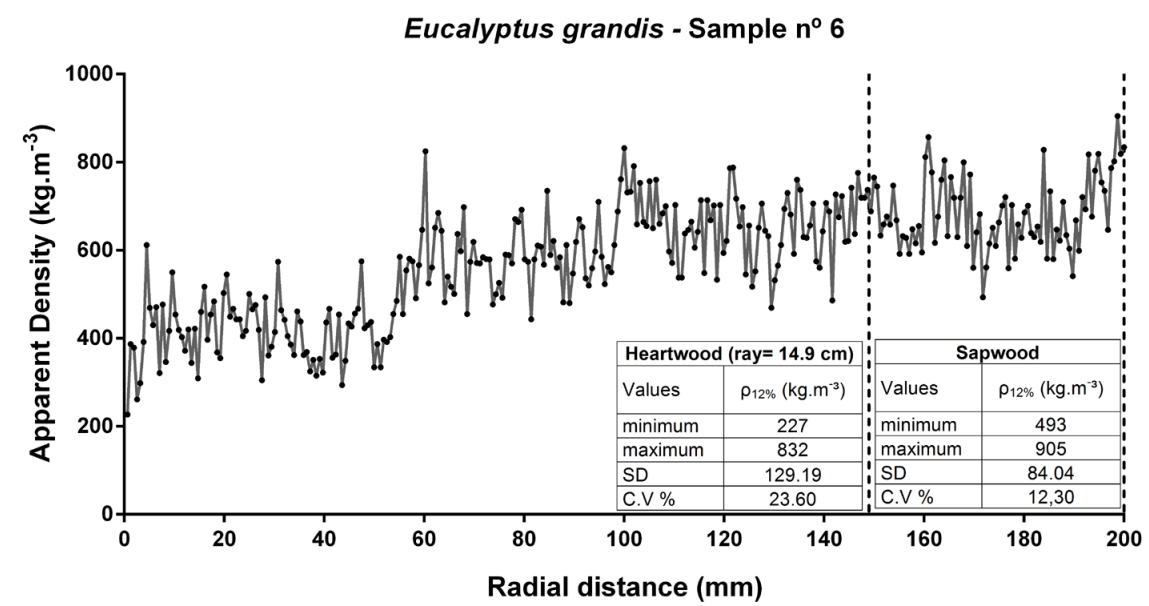

Figure 4 - Densitometry profile (apparent density) of Eucalyptus grandis- tree no 6, determined by the attenuation gamma radiation technique.

TABLE II

Weighted basic $\left(\rho_{b}\right)$ and apparent $\left(\rho_{12 \%}\right)$ mean densities (followed by standard deviation) of heartwood and sapwood regions and of the entire disk.

\begin{tabular}{|c|c|c|c|c|c|c|}
\hline \multirow{2}{*}{ Species } & \multicolumn{3}{|c|}{$\rho_{\mathrm{b}}\left(\mathrm{kg} \cdot \mathrm{m}^{-3}\right)$} & \multicolumn{3}{|c|}{$\rho_{12 \%}\left(\mathrm{~kg} \mathrm{~m}^{-3}\right)$} \\
\hline & Heartwood & Sapwood & Disk & Heartwood & Sapwood & Disk \\
\hline C. citriodora & $721(34.5)^{\mathrm{aA}}$ & $698(50.9)^{\mathrm{aA}}$ & $715(27.9)^{a}$ & $933(18.4)^{\mathrm{aA}}$ & $899(27.0)^{\text {aA }}$ & $924(41.1)^{\mathrm{a}}$ \\
\hline E. tereticornis & $703(59.6)^{\mathrm{aA}}$ & $647(86.9)^{\mathrm{abA}}$ & $692(40.4)^{\mathrm{a}}$ & $910(38.2)^{\mathrm{aA}}$ & $826(54.9)^{\mathrm{abA}}$ & $892(59.3)^{\mathrm{a}}$ \\
\hline E. grandis & $538(43.5)^{\mathrm{bA}}$ & $593(60.1)^{\mathrm{bA}}$ & $564(40.2)^{b}$ & $672(62.1)^{\mathrm{bA}}$ & $749(87.5)^{\mathrm{bA}}$ & $707(56.1)^{b}$ \\
\hline
\end{tabular}

In the same column, values followed by at least one lowercase same letter do not differ by Tukey test $(\mathrm{p}<0.05)$.

In the same line, for the same property, average followed by at least one uppercase do not differ by Student's $t$ test $(p<0.05)$.

can be observed that the maximum and minimum values were higher for sapwood and the coefficient of variation was higher in heartwood.

For all species the weighted mean basic density (Table II) ranged from 538 to $721 \mathrm{~kg} \cdot \mathrm{m}^{-3}$ in the heartwood region and from 593 to $698 \mathrm{~kg} \cdot \mathrm{m}^{-3}$ in the sapwood region. Apparent weighted mean density (at mass and volume 12\% MC) ranged from 672 to $932 \mathrm{~kg} \cdot \mathrm{m}^{-3}$ at the heartwood region and from 749 to $899 \mathrm{~kg} \cdot \mathrm{m}^{-3}$ in the sapwood region.

Wood of Corymbia citriodora showed the highest values (both basic and apparent density) of the entire disk and also in the two regions of the wood (heartwood and sapwood), but these values did not differ statistically from the results obtained for Eucalyptus tereticornis. Eucalyptus grandis was the species that showed lower density, with statistical difference to other species studied for heartwood regions; for the sapwood region, it only statistically differed from Corymbia citriodora.

\section{UNIFORMITY INDEX}

The uniformity index (Table III) ranged from 187 to 267 in the wood as a whole, from 191 to 258 in the heartwood and from 154 to 157 in the sapwood. The Eucalyptus grandis was the species with higher indexes, indicating less uniformity in both heartwood regions and entire disk. However, the sapwood of E. grandis had the lowest index.

For all species, sapwood revealed more uniformity (lower index) than heartwood and these results confirm the first impression obtained in a visual analysis. Moreover, it can be noted that heartwood had a greater contribution in the index for the entire disk. 
TABLE III

Uniformity index of heartwood and sapwood regions and of the entire disk.

\begin{tabular}{cccc}
\hline \multirow{2}{*}{ Species } & \multicolumn{3}{c}{ Uniformity index } \\
\cline { 2 - 4 } & Heartwood & Sapwood & Disk \\
\hline Corymbia citriodora & $195^{\mathrm{bA}}$ & $156^{\mathrm{aB}}$ & $187^{\mathrm{bA}}$ \\
Eucalyptus tereticornis & $191^{\mathrm{bA}}$ & $157^{\mathrm{aB}}$ & $194^{\mathrm{bA}}$ \\
Eucalyptus grandis & $258^{\mathrm{aA}}$ & $154^{\mathrm{aB}}$ & $267^{\mathrm{aA}}$ \\
\hline
\end{tabular}

In the same column, average followed by at least one lowercase same letter do not differ by Tukey test $(\mathrm{p}<0.05)$. In the same line, average followed by at least one uppercase do not differ by Tukey test $(\mathrm{p}<0.05)$.

\section{DISCUSSION}

The methods for determining the density of wood by means of the use of X-rays or beta particles, although they present good accuracy, they have limited application for sample thickness. So there is sensitivity in determinations, the average thickness of the samples should not exceed $1.0 \mathrm{~cm}$ for X-rays and $2.0 \mathrm{~cm}$ for beta ${ }^{90} \mathrm{Sr}$. However, in many situations, it is necessary to work with thicker samples. In such cases, the use of Gamma radiation has been shown adequate for working with samples ranging from 1.0 to $40.0 \mathrm{~cm}$ thickness (Rezende et al. 1999). Therefore, in this study, the attenuation gamma radiation technique was more suitable because of the possibility of using the entire disks with $3.0 \mathrm{~cm}$ thickness, in addition, this technique has an easier and faster preparation of the sample.

Long-rotation Eucalyptus plantations are specially indicated for timber production considering higher yields in sawmill, increased stability of the wood due to the greater amount of heartwood (Sella 2001, Nawrot et al. 2008) - although the density variability is higher in heartwood than in sapwood (Bossu et al. 2016) and uniformity in color (Haselein et al. 2004).

In the past, heartwood formation was viewed as an aging process in which a gradual loss of metabolic activity led to cell death, but it is now clear that it defines an active program of tissue senescence. A better understanding is needed of how the loss of conductive function in xylem occurs with age, and how this process differs across species (Spicer 2005).

The results presented in Table I suggest that there is no pattern in heartwood formation correlated with age or size of the trees. The relationships are stronger between growth rate and sapwood width than between growth rate and number of rings in sapwood. That is, the amount of wood needed for physiological process is independent of how that wood was developed (Gartner and Meinzer 2005). Lachenbruch et al. (2011) discuss the radial variation in wood structure and function and state that the particular radial patterns are variable in hardwoods vs. softwoods, and among growth forms, species, environments, and plant parts. The authors have also listed similarities and differences between trees that differ in age but not size, or in size but not age, and it is possible to see that there are numerous candidate functions on which natural selection may have acted, and that there is no one set of similarities or differences from which we can infer why a certain species and trait is more closely correlated with one of the independent variables (age or size) than with the other; there are sets of traits that are most common for a given category of plants.

The largest percentage of heartwood area (and lower percentage of sapwood area) was found in Eucalyptus tereticornis, followed by Eucalyptus grandis, and finally, Corymbia citriodora. Oliveira et al. (1999) in a study of adult trees of seven species of Eucalyptus (with approximately 19 years old), 
found lower percentage of heartwood in the trees of Corymbia citriodora compared to E. grandis trees, results that coincide with those obtained in this study. Using samples in the basal portion of the main stem, the authors report a mean percentage of heartwood of 51.6 for Corymbia citriodora, 67.1 for E. grandis and 67.6 for E. tereticornis.

Silva (2002) also studied 20 and 25 years old trees of the Eucalyptus grandis and observed heartwood and sapwood percentages and heartwood/sapwood relation of 72.4, 27.6 and 2.83 respectively for 20 years old trees. The heartwood percentage and heartwood/sapwood relation are slightly higher than those obtained for the same species in this study.

The mean basic density of Eucalyptus was studied by many authors, considering the entire disk (heartwood + sapwood). The relationship between wood density and relation heartwood/ sapwood is not a rule, in general, because of the large variability between species and the percentage of juvenile wood, among other factors (Pereira et al. 2013). The evolution of wood density within tree stems varies according to species, following typical radial and longitudinal patterns that are strongly correlated with tree age, size and growth (Lachenbruch et al. 2011).

For young plantations $(<20$ years old) of Eucalyptus grandis it can be compiled (Table IV) that basic density varied from $424-445 \mathrm{~kg} \cdot \mathrm{m}^{-3}$ for 6 years old trees (Pillai et al. 2013), $525 \mathrm{~kg} \cdot \mathrm{m}^{-3}$ - for 10.5 years old trees (Sturion et al. 1987) and varied from 570 - $590 \mathrm{~kg} \cdot \mathrm{m}^{-3}$ - for 17 - 18 years old trees (Ciniglio 1998, Gonçalez et al. 2006, Lopes et al. 2011). For older plantations ( $>20$ years old) basic density varied from $690 \mathrm{~kg} \cdot \mathrm{m}^{-3}$ to $750 \mathrm{~kg} \cdot \mathrm{m}^{-3}$ - for 20 years old trees (Ashley and Ozarska 2000), suggesting, in general, a direct relation between basic density and age of the trees. In fact, the results here obtained $\left(564 \mathrm{~kg} . \mathrm{m}^{-3}\right)$ are very close to those of studies with similar age of the plantations $(<20$ years). The apparent densities were 490, 560 to
$680 \mathrm{~kg} \cdot \mathrm{m}^{-3}$ in three different radial positions (inner, intermediate and external, respectively) - for 23 years old trees (Oliveira et al. 2012), indicated increased wood density from pith to bark. The results here obtained, higher than these (Oliveira et al. 2012) also suggested increased wood density in the radial direction (heartwood - $672 \mathrm{~kg} \cdot \mathrm{m}^{-3}$; sapwood $749 \mathrm{~kg} . \mathrm{m}^{-3}$ ) although no statistical differences were observed.

For young plantations $(<20$ years old) of Corymbia citriodora values of $715 \mathrm{~kg} . \mathrm{m}^{-3}$ - for 10.5 years old trees (Sturion et al. 1987) and 730 $\mathrm{kg} . \mathrm{m}^{-3}$ - for 16 years old trees (Oliveira et al. 2005) were obtained for basic density. For older plantations (60 years old) Lourençon et al. (2013) obtained for basic density values from 550 to 820 kg. $\mathrm{m}^{-3}$ in 5 positions in radial direction (pith - bark). For apparent density some authors obtained values of $840 \mathrm{~kg} \cdot \mathrm{m}^{-3}$ - for 23 years old trees (Oliveira et al. 2012), 970 - $1200 \mathrm{~kg} . \mathrm{m}^{-3}$ for 29 years old trees (Benjamin and Ballarin 2009) and $700-860 \mathrm{~kg} \cdot \mathrm{m}^{-3}$ for 60 years old trees (Lourençon et al. 2013). The values here obtained were similar to those found in the literature, both to basic density $\left(715 \mathrm{~kg} \cdot \mathrm{m}^{-3}\right)$ and apparent density $\left(924 \mathrm{~kg} \cdot \mathrm{m}^{-3}\right)$.

For young plantations $(<20$ years old) of Eucalyptus tereticornis, basic density varies from $592 \mathrm{~kg} . \mathrm{m}^{-3}$ - for 10.5 years old trees (Sturion et al. 1987) to $660 \mathrm{~kg} \cdot \mathrm{m}^{-3}$ - for 16 years old trees (Oliveira et al. 2005). The values found by the authors are lower than those obtained here and this inferiority in values probably is associated with younger trees used in their study (16 and 10.5 years old).

For all the species studied, literature reports a tendency of increase in density in the radial direction (pith to bark) which occurred exclusively for $E$. grandis in this study, probably due to the lower age of these trees $(<20$ years old). However, for older tress, many authors observed a gradual increase in basic density followed by stability near to the bark (Carmo 1996, Gatto et al. 2010, Lopes et al. 2011, Ribeiro et al. 2011, Lourençon et al. 2013) due to 
TABLE IV

Summary table - density values reported in the literature for $E$. grandis, $E$. tereticornis and $C$. citriodora.

\begin{tabular}{|c|c|c|c|c|}
\hline \multirow{2}{*}{ Species } & \multirow{2}{*}{ Age (years) } & \multicolumn{2}{|c|}{ Density $\left(\mathrm{kg} \cdot \mathrm{m}^{-3}\right)$} & \multirow{2}{*}{ Reference } \\
\hline & & Basic & Apparent & \\
\hline \multirow{3}{*}{$\begin{array}{l}\text { E. grandis } \\
(<20 \text { years })\end{array}$} & 6 & $424-445$ & - & Pillai et al. 2013 \\
\hline & 10.5 & 525 & - & Sturion et al. 1987 \\
\hline & $17-18$ & $570-590$ & - & Ciniglio 1998, Gonçalez et al. 2006, Lopes et al. 2011 \\
\hline \multirow{2}{*}{$\begin{array}{l}\text { E. grandis } \\
(>20 \text { years })\end{array}$} & 28 & $690-750$ & - & Ashley and Ozarska 2000 \\
\hline & 23 & - & $490-680$ & Oliveira et al. 2012 \\
\hline \multirow{3}{*}{$\begin{array}{l}\text { C. citriodora } \\
\text { (<20 years) }\end{array}$} & 10.5 & 715 & - & Sturion et al. 1987 \\
\hline & 16 & 730 & & Oliveira et al. 2005 \\
\hline & 60 & $550-820$ & - & Lourençon et al. 2013 \\
\hline \multirow{3}{*}{$\begin{array}{l}\text { C. citriodora } \\
\text { (>20 years) }\end{array}$} & 23 & - & 840 & Oliveira et al. 2012 \\
\hline & 29 & - & $970-1200$ & Benjamin and Ballarin 2009 \\
\hline & 60 & - & $700-860$ & Lourençon et al. 2013 \\
\hline \multirow{2}{*}{$\begin{array}{l}\text { E. tereticornis } \\
(<20 \text { years })\end{array}$} & 10.5 & 592 & - & Sturion et al. 1987 \\
\hline & 16 & 660 & - & Oliveira et al. 2005 \\
\hline
\end{tabular}

changes of the cambial meristem - the wall thickness of fibers is increased and the frequency and number of vessels decreases to supply the mechanical and physiological requirements derived the process of development of trees (Sette Jr et al. 2012).

As introduced in Figure 5, in C. citriodora (28 years old) and E. tereticornis (35 years old) weighted mean apparent density showed lower variations between heartwood and sapwood compared to E. grandis (18 years old). In older trees, heartwood contains a greater amount of mature wood (in comparison with heartwood of younger trees) which promotes increase in densities (Malan 1988, Bao et al. 2001, Passialis and Kiriazakos 2004, Santos et al. 2004, Tomazello Filho 2006, Sette Jr et al. 2010, Oliveira et al. 2012, Bal and Bektaş 2012). Differently, E. grandis trees (18 years old) showed lower densities in heartwood and a tendency to increase density along the radius (increase of $11.4 \%$ from heartwood to sapwood region) as an effect of the juvenility of wood in these trees. Despite these tendencies, the density showed no statistical difference between heartwood and sapwood.
As reported in Table III, the sapwood presented higher uniformity $(\cong 160)$ in all species studied, which characterizes mature wood. In the heartwood region, great proportions of juvenile wood make the density less uniform and this was particularly observed in the heartwood of Eucalyptus grandis (younger trees). In older trees (E. tereticornis and $C$. citriodora), despite the difference in homogeneity between heart and sapwood (Table III), heartwood revealed uniformity indexes (191 and 195) closer to those of their respective sapwood regions. In fact, younger trees (E. grandis) showed a larger heterogeneity in heartwood (258), due to the fact that most part of it was produced in the juvenile stage of the tree. E. grandis showed larger variation (40.3) due to the predominance of juvenile wood as already commented. Differently from the density analyses, in all species studied there was statistical differences between uniformity indexes for heartwood and sapwood regions.

Alzate (2004) found uniformity index of 169.5 for Eucalyptus grandis. The uniformity index here obtained (Table III) was higher. These indexes are inferior to those of presented in general by conifers 

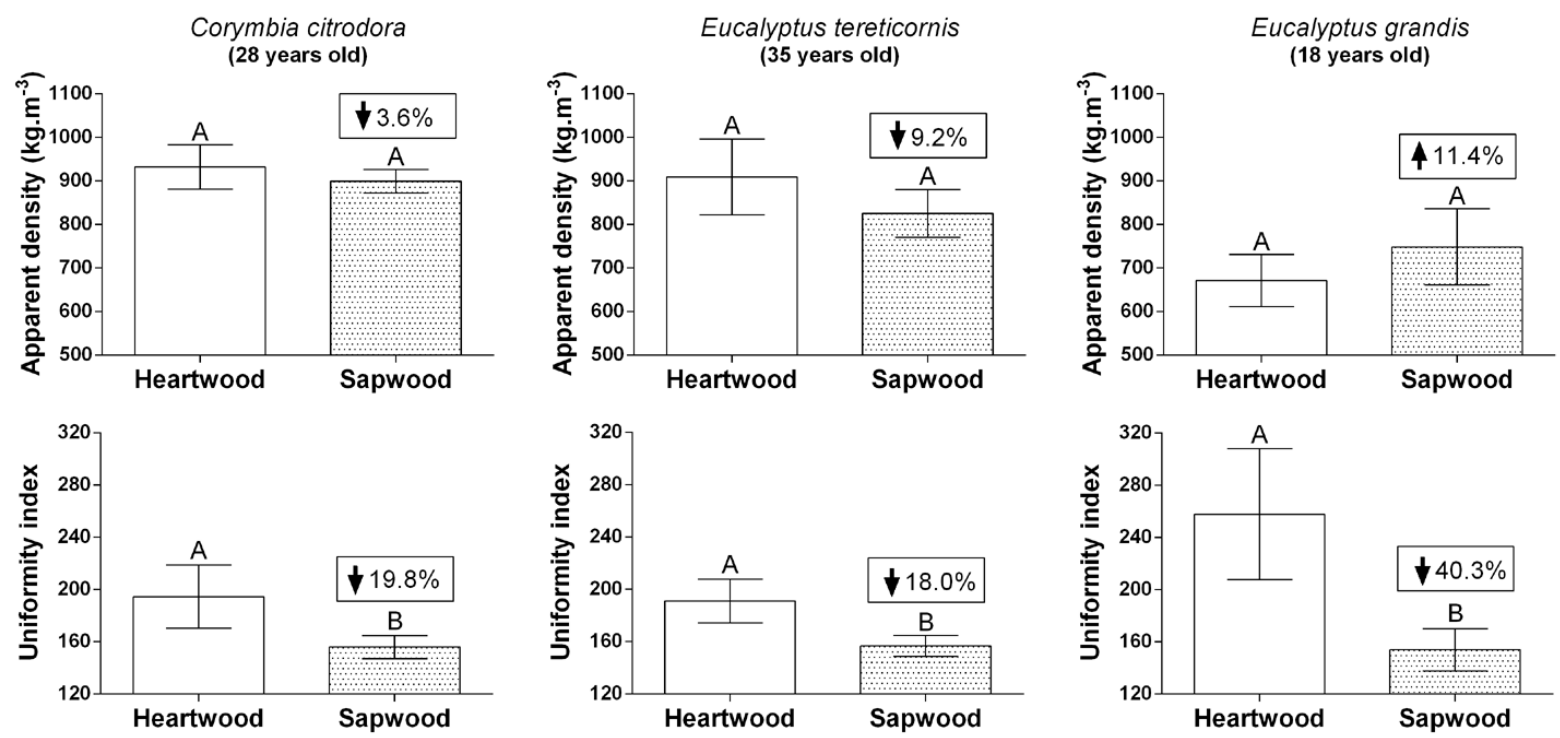

Figure 5 - Histograms of variation in weighted apparent density and uniformity index (with standard deviation) in the heartwood and sapwood of the three species studied.

from temperate climate in which is outstanding the alternation of annual growth rings. Echols (1973) reported uniformity index from 220 to 317 for conifers.

\section{CONCLUSIONS}

The percentage of heartwood area was higher in all studied species, and the Eucalyptus tereticornis was the specie with the highest percentage of heartwood, followed by Eucalyptus grandis, and Corymbia citriodora.

The higher basic and apparent density values were found in the Corymbia citriodora, followed by Eucalyptus tereticornis, and Eucalyptus grandis, however, in general, for the trees and species studied from a physical point of view it can be stated that heartwood and sapwood fractions have similar quality in terms of densities, considering that no significant differences were obtained in these properties.

Despite lower areas of sapwood in relation to heartwood, the density is more uniform, possibly due to the greater amount of mature wood, while in the heartwood the amount of juvenile wood makes the density along this fraction less uniform.

The results justify the inclusion of the density uniformity index as a quality parameter for Eucalyptus wood, calculated by the applying of the punctual values of apparent density by gamma radiation. This parameter can be considered a very important tool for qualifying wood for timber purposes, but primarily for wood-based composite materials, where the homogeneity of the wood influences intensely on the quality of the final product.

\section{ACKNOWLEDGMENTS}

To the financial support from Fundação de Amparo à Pesquisa do Estado de São Paulo (FAPESP - 2012/18704-1), and PREMA Tecnologia e Comércio Ltda. for the provided material.

\section{REFERENCES}

ALZATE SBA. 2004. Caracterização da madeira de árvores de clones de Eucalyptus grandis, E. saligna e E. grandis $\mathrm{x}$ urophylla, 133 p. Tese (Doutorado em Recursos Florestais) - Escola Superior de Agricultura "Luiz de Queiroz", Universidade de São Paulo, Piracicaba. 
ARANTES MDC. 2009. Variação nas características da madeira e do carvão de um clone de Eucalyptus grandis W. Hill ex Maiden x Eucalyptus urophylla S. T. Blake, 149 p. Tese (Doutorado em Ciência e Tecnologia da Madeira) - Universidade Federal de Lavras, Lavras.

ASHLEY PN AND OZARSKA B. 2000. Furniture from young plantation eucalypts. In: The future of Eucalyptus for wood products. Launceston, Tasmania. Proceedings.... Launceston: IUFRO, p. 176-184.

BAMBER RK. 1976. Heartwood, its function and formation. Wood Sci Technol 10(1): 1-8.

BAMBER RK. 1981. Sapwood and heartwood. NSW Department of Primary Industries. Science and Research Division. Forest Resources Research. Technical Papers 2: $1-7$.

BAMBER RK AND FUKAZAWA K. 1985. Sapwood and heartwood: a review. Forestry Abstract, Wallingford, 6(9): 567-580.

BAL CB AND BEKTAŞ İ. 2012. The effects of heat treatment on physical properties of juvenile wood and mature wood of Eucalyptus grandis. Bioresources 7(4): 5117-5127.

BAO FC, JIANG ZH, JIANG XM, LU XX, LUO XQ AND ZHANG SY. 2001. Differences in wood properties between juvenile wood and mature wood in 10 species grown in China. Wood Sci Technol 35: 363-375.

BENJAMIN CA AND BALLARIN AW. 2009. Variação radial da densidade aparente da madeira de Corymbia (Eucalyptus) citriodora com 29 anos de idade. Energ Agric 24(2): 29-46.

BODIG J AND JAYNE BA. 1993. Mechanics of Wood and Wood Composites. Krieger publishing company, Malabar, Florida, 712 p.

BOSSU J, BEAUCHÊNE J, ESTEVEZ Y, DUPLAIS C AND CLAIR B. 2016. New insights on wood dimensional stability influenced by secondary metabolites: the case of a fast-growing tropical species Bagassa guianensis aubl. PLoS ONE 11(3): e0150777.

BURGER LM AND RICHTER HG. 1991. Anatomia da madeira. São Paulo: Nobel, 154 p.

CAMPBELL AG, KIM W AND KOCH P. 1990. Chemical variation in lodgepole pine with sapwood/heartwood stem height and variety. Wood Fiber Sci, Hanover, Pennsylvania. 22(1): 22-30.

CARMO APT. 1996. Avaliação de algumas propriedades da madeira de seis espécies de eucalipto, 74 p. Dissertação (Mestrado em Ciência Florestal) - Universidade Federal de Viçosa, Viçosa. (Unpublished).

CHEN CL. 1991. Lignins: occurrence in woody tissues, isolation, reactions and structure. In: Lewin $M$ and Goldstein IS (Eds), Wood structure and composition. Marcel Dekker, New York, p. 183-263.

CINIGLIO G. 1998. Avaliação da madeira serrada de Eucalyptus grandis e Eucalyptus urophylla. Piracicaba, 73 p. Dissertação (Mestrado) - Escola Superior de Agricultura Luiz Queiroz, Universidade de São Paulo, Piracicaba. (Unpublished).

CLARKE CRE, GARBUTT DCF AND PEARCE J. 1997. Growth and wood properties of provenances and tree of nine Eucalypt species. Appita J 50(2): 121-130.

ECHOLS RM. 1973. Uniformity of wood density assessed from X-rays of increment cores. Wood Sci Technol 7: 3444.

FERRAZ ESB AND MANSEL RS. 1979. Determining water content and bulk density of soil gamma ray attenuations method. IFAS Technical Bulletin (807): 51.

GARTNER BLAND MEINZER FC. 2005. Structure-Function relationships in sapwood water transport and storage. In: Holbrook NM and Zwieniecki M (Eds), Vascular Transport in Plants, Elsevier/Academic Press, Oxford, p. 307-331.

GATTO DA, HASELEIN CR, BULIGON EA, CALEGARI L, STANGERLIN DM, MELO RRM, TREVISAN R AND SANTINI EJ. 2010. Estimativa da idade de segregação do lenho juvenil a adulto de Carya illinoinensis (Wangenh) K. Koch por meio de parâmetros anatômicos da madeira. Cienc Florest 20(4): 675-682.

GONÇALEZ JC, BREDA LCS, BARROS JFM, MACEDO DG, JANIN G, COSTA AF AND VALE AT. 2006. Características tecnológicas da madeira de Eucalyptus grandis W.Hill ex Maiden e Eucalyptus cloeziana F. Muell visando ao seu aproveitamento na indústria moveleira. Cienc Florest 16(3): 329-341.

GRABNER M, WIMMER R, GIERLINGER N, EVANS R AND DOWNES G. 2005. Heartwood extractives in larch and effects on X-ray densitometry. Can J For Res 35: 2781-2786.

HASELEIN CR, LOPES MC, SANTINI EJ, LONGHI SJ, ROSSO S, FERNANDES DLG, MENEZES LF. 2004. Características tecnológicas da madeira de árvores matrizes de Eucalyptus grandis. Cienc Florest 14(2): 145-155.

HAZENBERG G AND YANG KC. 1991. Sapwood/heartwood width relationships with tree age in balsam fir. IAWA J 12(1): 95-99.

HILLIS WE. 1971. Distribution, properties and formation of some wood extractives. Wood Sci Technol 5: 272-289.

HILLIS WE. 1972. Properties of eucalypt woods of importance to the pulp and paper industry. Appita 26: 113-122.

HILLIS WE. 1984. Wood quality and utilization. In: Hillis WE and Brown AG (Eds), Eucalyptus for Wood Production. CSIRO/Academic Press, Melbourne, Australia, p. 259289.

HILLIS WE. 1987. Heartwood and tree exudates. Berlin: Springer-Verlag, $268 \mathrm{p}$.

HOLMBOM BR, PRANOVICH AV, SUNDBER GA AND BUCHER TJ. 2000. Charged groups in wood and mechanical pulps. In: Kennedy JF, Phillips GO and 
Williams PA (Eds), Pulp for papermaking. Woodhead, Cambridge, p. 109-119.

KAI Y. 1991. Chemistry of extractives. In: Hon DS and Shiraishi N (Eds), Wood and cellulosic chemistry. Marcel Dekker, New York, p. 213-241.

KORT I. 1992. Relationships between sapwood amount, latewood percentage, moisture content and crown vitality of Douglas-fir, Pseudotsuga menziesii. IAWA J 14(4): 413427.

LACHENBRUCH B, MOORE JR AND EVANS R. 2011. Radial variation in wood structure and function in woody plants, and hypotheses for its occurrence. In: Meinzer FC, Lachenbruch B and Dawson TE (Eds), Size- and Agerelated Changes In Tree Structure and Function. Tree Physiology, Springer 4: 121-164.

LOPES CSD, NOLASCO AM, TOMAZELLO FILHO M, DIAS CTS AND PANSINI A. 2011. Estudo da massa específica básica e da variação dimensional da madeira de três espécies de eucalipto para a indústria moveleira. Cienc Florest 21(2): 315-322.

LOURENÇON T, MATTOS BD, GATTO DA, DELUCIS R. 2013. Physical properties of Corymbia citriodora wood in radial direction. Sci For 41(99): 369-375.

MALAN FS. 1988. Wood density variation in four trees of South African grown Eucalyptus grandis (Hill ex Maiden). S Afr Forestry J 144(1): 36-42.

MCKIMM RJ. 1985. Characteristics of wood of young fastgrown trees of Eucalyptus nitens Maiden with reference to provenance variation. I. Variation in growth, strain and density associated with provenance. Aust Forest Res 15: 207-218.

MIRANDA I, GOMINHO J, LOURENÇO A AND PEREIRA H. 2006. The influence of irrigation and fertilization on heartwood and sapwood contents in 18-year-old Eucalyptus globulus trees. Can J For Res 36: 2675-2683.

NAWROT M, PAZDROWSKI W AND SZYMAŃSKI M. 2008. Dynamics of heartwood formation and axial and radial distribution of sapwood and heartwood in stems of European larch (Larix decidua Mill.). J For Sci 54 (9): 409-417.

OLIVEIRA AMF, LELIS AT, LEPAGE ES, LOPEZ GAC, OLIVEIRA LCS, CAÑEDO MD AND MILANO S. 1986. Agentes destruidores da madeira. In: Lepage ES (Ed), Manual de preservação de madeiras. São Paulo: IPT, SICCT, 1(5): 99-278.

OLIVEIRA BRU, LATORRACA JVF, TOMAZELLO FILHO M, PALERMO GPM, CARVALHO AM AND PASTRO MS. 2012. Microdensitometria de raios X aplicada na determinação da variação da densidade do lenho de árvores de Eucalyptus grandis W. Hill. Sci For 40(93): 103-112.

OLIVEIRA JTS, HELLMEINSTER JC, SIMÕES JW AND TOMAZELLO FILHO M. 1999. Caracterização da madeira de sete espécies de eucaliptos para a construção civil. Sci For (56): 113-124.

OLIVEIRA JTS, TOMAZELLO FILHO M AND SILVA JC. 2005. Resistência natural da madeira de sete espécies de eucalipto ao apodrecimento. Rev Árvore 29(6): 993-998.

PALERMO GPM, LATORRACA JVF, SEVERO ETD, REZENDE MA AND ABREU HS. 2004. Determinação da densidade da madeira de Pinus elliottii Engelm, através de atenuação de radiação gama comparada a métodos tradicionais. Floresta Ambient 11(1): 1-6.

PANSHIN AJ AND DE ZEEUW WC. 1980. Textbook of wood technology, vol. 1, McGraw-Hill, New York, USA.

PARRISH WB. 1961. Detecting defects in wood by the attenuation of gamma rays. For Sci 2: 136-143.

PASSIALIS C AND KIRIAZAKOS A. 2004. Juvenile and mature wood properties of naturally-grown fir trees. Holz RohWerkst 62(6): 476-478.

PEREIRA BLC, OLIVEIRA AC, CARVALHO AMML, CARNEIRO ACO, VITAL BR AND SANTOS LC. 2013. Correlações entre a relação Cerne/Alburno da madeira de eucalipto, rendimento e propriedades do carvão vegetal. Sci For 41(98): 217-225.

PILLAI PKC, DHAMODARAN TK AND SANKARAN KV. 2013. Wood density and heartwood proportion in eucalyptus trees from intensively-managed short-rotation plantations in Kerala, India. J Trop For Sci 25(2): 220-227.

PINHEIRO MA. 2013. Influência das dimensões da madeira na secagem e nas propriedades do carvão vegetal, 77 p. Dissertação (Mestrado em Ciência Florestal), Universidade Federal de Viçosa, Viçosa. (Unpublished).

REZENDE MA. 1997. Uma abordagem convencional sobre as principais características físicas da madeira, com ênfase para retratibilidade, massa específica e técnica de atenuação de radiação gama, 138 p. Tese (Livre Docência) - Faculdade de Ciências Agronômicas, Universidade Estadual Paulista, Botucatu. (Unpublished).

REZENDE MA, SAGLIETTI JRC AND CHAVES R. 1998. Specific gravity variation of Eucalyptus grandis wood at 8 years old in function of a different productivity indexes. Sci For (53): 71-78.

REZENDE MA, GUERRINI IA, DUCATTI C AND QUINTANA IR. 1999. Utilização da técnica de atenuação da radiação gama no estudo das variações da massa específica do Pinus oocarpa aos 24 anos de idade. In: VII Congresso Geral de Energia Nuclear, 1999, Belo Horizonte-MG. VII CGEN. Rio de Janeiro-RJ: ABEN.

RIBEIRO AO, MENDES LM, MORI FA, ZIECH RQS AND MENDES RF. 2011. Variação da densidade básica da madeira de Toona ciliata Roem cultivada em diferentes localidades. Sci For 39(91): 359-366.

SANTOS PET, GARCIA JN, GERALDI IO. 2004. Posição da tora na árvore e sua relação com a qualidade da madeira serrada de Eucalyptus gradis. Sci For (66): 142-151. 
SELLA RL. 2001. Técnicas silviculturais e de exploração para a obtenção de madeira de qualidade para a laminação e serraria In: Seminário Madeira de Eucalipto: Tendências e Usos. Curitiba. Anais, Curitiba: FUPEF, p. 19-24.

SETTE JÚNIOR CR, OLIVEIRA IR, TOMAZELLO FILHO M, YAMAJI FM AND LACLAU JP. 2012. Efeito da idade e posição de amostragem na densidade e características anatômicas da madeira de Eucalyptus grandis. Rev Árvore 36(6): 1183-1190.

SETTE JÚNIOR CR, TOMAZELLO FILHO M, DIAS CTS AND LACLAU JP. 2010. Crescimento em diâmetro do tronco das árvores de Eucalyptus grandis W. Hill. ex. Maiden e relação com as variáveis climáticas e fertilização mineral. Rev Árvore 34(6): 979-990.

SHUPE TF, HSE CY, CHOONG ET AND GROOM LH. 1997. Differences in some chemical properties of innerwood and outerwood from five silviculturally different loblolly pine stands. Wood Fiber Sci 29(1): 91-97.

SILVA JC. 2002. Caracterização da madeira de Eucalyptus grandis Hill ex. Maiden de diferentes idades visando sua utilização na indústria moveleira, 160 p. Tese (Doutorado em Ciências Florestais) - Universidade Federal do Paraná, Curitiba.

SINGLETON R, DEBELL DS AND GARTNER BL. 2003. Effect of extraction on wood density of western hemlock (Tsuga heterophylla (raf.) sarg). Wood Fiber Sci 35(3): 363-369.

SMITH HG, WALTERS J AND WELLWOOD RW. 1966. Variation in sapwood thickness of Douglas-fir in relation to tree and section characteristics. Forest Sci 12(1): 87103.

SPICER R. 2005. Senescence in secondary xylem: heartwood formation as an active developmental program. In: Holbrook NM and Zwieniecki M (Eds), Vascular Transport in Plants. Elsevier/Academic Press, Oxford, p. 457-475.

STURION JA, PEREIRA JCD AND ALBINO JC. 1987. Avaliação da produtividade energética da madeira e do carvão de doze espécies de Eucalyptus em Uberaba-MG. Colombo: EMBRAPA-CNPF.
TOMAZELLO FILHO M. 2006. Efeito da irrigação e fertilização nas propriedades do lenho de árvores de Eucalyptus grandis x urophylla, 135 p. Tese (LivreDocência) - Escola Superior de Agricultura Luiz de Queiroz, Piracicaba. (Unpublished).

TOMAZELLO FILHO M, BRAZOLIN S, CHAGAS MP, OLIVEIRA JTS, BALLARIN AW AND BENJAMIN CA. 2008. Application of $\mathrm{x}$-ray technique in nondestructive evaluation of eucalypt wood. Maderas-Cienc Technol 10(2): 139-149.

TREVISAN R, HASELEIN CR, MELO RR, STANGERLIN DM, BELTRAME R, GATTO DA AND CALEGARI L. 2008. Variação radial da massa específica básica da madeira de Eucalyptus grandis W. Hill ex Maiden. Floresta 38(3): 553-559.

WIEDENHOEFT AC. 2012. Structure and function of wood. In: Rowell RM (Ed), Handbook of wood chemistry and wood composites, $2^{\text {nd }}$ ed., CRC Press, Florida, USA, p. 09-32.

WILKES J. 1991. Heartwood development and its relationship to growth in Pinus radiata. Wood Sci Technol 25: 85-90.

WILKINS AP. 1989a. Implications of silviculturally induced variation of wood density and heartwood formation in Eucalyptus grandis. In: Pacific Wood Anatomy Conference, Laguna. Proceedings ... Laguna: IUFRO, p. 359-368.

WILKINS AP. 1989b. Wood color of Eucalyptus grandis in response to silvicultural treatment. In: Pacific Wood Anatomy Conference, Laguna. Proceedings ... Laguna: IUFRO, p. 115-112.

WINANDY JE AND MORRELL JJ. 1993. Relationship between incipient decay, strength and chemical composition of Douglas-fir heartwood. Wood Fiber Sci 25(3): 278-288.

YANG KC AND HAZENBERG G. 1991. Sapwood and heartwood width relationship to tree age in Pinus banksiana. Can J For Res 21(4): 521-525. 